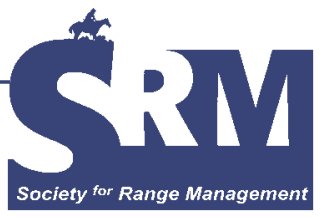

\title{
Revegetation Priorities
}

\section{Terrance Booth and Kenneth P. Vogel}

\section{Introduction}

Revegetation is a needed means of mitigating man-made and natural disturbance. Our current ability to address environmental insults contrasts sharply with that existing when John Muir first sowed the roots of environmental awareness or Aldo Leopold and Hugh H. Bennett inspired a land ethic and a sense of stewardship. We now have considerable revegetation science and experience and - equally important—viable native-seed and revegetation industries expert in repairing environmental damage. Through the National Plant Materials program, related and usually cooperative work within state universities and other entities, and the development of ecological service industries, our society has heeded Leopold's call to take pride in the "husbandry" of wild plants. ${ }^{1}$ Yet, wild-plant husbandry is now being questioned, as is the wisdom of much of the knowledge, experience, and use of plant materials developed over the past 3 to 5 decades.

Controversy exists over the seed sources to be preferred and the intended outcome of revegetation projects. We have agreement that disturbed sites need to be stabilized, erosion minimized, and basic ecosystem processes maintained, but disagreement on the extent that revegetation should exactly reproduce the predisturbance plant community and within-species genetic composition. It is a question of priorities. Should preferential use of local plant materials be advocated as the best method to preserve genetic composition, or should available cultivars of native species, and other source identified materials, be employed as the most expedient means for timely soil stabilization and long-term ecosystem-process restoration?

This article has been peer reviewed.
A cultivar is a variety, strain, or population of known genetic origin, produced under cultivation in a way to ensure its genetic integrity is maintained.

There is agreement among land managers, Federal and state agencies, conservation groups, and scientists that the decisions should be based on research and science. There are hundreds of species on the rangelands of North America and rigorous genetic and adaptation studies have been conducted on only a few, so the scientific information base is small in comparison to that of cultivated crops. Our intent here is to summarize key aspects of this problem, suggest some potential approaches and solutions, and encourage further research.

\section{Issues and Concerns}

Four questions underlie the cultivar/local-ecotype controversy:

1. Does farming for seed increase, change the genetic resources of cultivars or source-identified seeds being increased?

2. Do cultivars cause genetic pollution when seeded near wild stands?

3. What are the short-term and long-term ecological consequences of "outbreeding depression?"

4. Will cultivars directly or indirectly negatively affect the functional ecology of a system?

\section{Earth's History}

One of the basic assumptions for using local ecotypes in revegetation is that they are best adapted to the climate and 
site of the area to be revegetated. Since rangeland revegetation projects are expected to produce indefinitely sustainable plant populations, a preference for local ecotypes implies an assumption that the current climate will also continue indefinitely into the future. Paul and Hazel Delcourt writing in The Flora of North America review evidence that at least 20 glacial-interglacial cycles have influenced the floristic regions of North America. ${ }^{2}$ The last glacial to interglacial cycle gives us an idea of floristic changes that have occurred in the past 20 cycles. About 20,000 years ago ice sheets dominated the northern half of North America and glacial ice flowed east from the Rocky Mountains. Permafrost and tundra occurred across eastern Washington, Idaho, Montana, and Wyoming.

By 15,000 years ago the glaciers were retreating toward mountain summits and by 12,000 years ago lodgepole pine had colonized deglaciated terrain. The changing ice pattern was accompanied by changes in the jet stream, and in precipitation patterns. By 10,000 years ago forests had a greater variety of species and sagebrush steppes were developing in rain shadows east of the Cascades and Rocky Mountains. Between 10,000 and 7,000 years ago, the warmest and driest summers accentuated the stress of growing-season drought and produced more changes in the existing plant communities. The surprise is that these global-climate changes did not produce a large-scale evolution of new species. The Delcourts tell us these cycles mostly moved existing species and communities back and forth across the landscape with each glacial-to-interglacial sequence.

In history, as now, the continuum of change is constant.

What basic ecological processes allowed plant species to migrate and to adapt to change?

The Delcourts also write that the spread of paleoIndians influenced the distributions of certain plant species as well as the composition of plant communities. ${ }^{2}$ This was particularly true during the last 5,000 years when the people became more sedentary and "grew native and introduced plants for food." Thus, people in North America have influenced its vegetation for 12,000 years both directly and indirectly. That continues and may be accelerating with increased carbon dioxide in the atmosphere and its potential effects for global warming. The question that needs to be asked is whether local ecotypes or composite populations and cultivars with broad genetic bases are most likely to adapt to the changes of decades, and centuries, and millennia? Climatic history indicates that climate changes will occur-that change is a constant. Genetic diversity, both within and among species, is the foundation of sustainable populations. This principal has been repeatedly emphasized for reclamation seed mixes. ${ }^{3,4}$
Which seed sources are sustainable?

Genetic diversity is the foundation of population stability and sustainability.

\section{Plant Evolution}

The preferential use of local plant types is often justified using Darwin's principal of natural selection. Advocates argue either that natural selection is an optimizing force in the evolution of local types over other variants of a species (plant competition is identified as the selecting force) or that local types are more compatible with the local environment (environment is the selecting force). Either way, natural selection is viewed as an optimizing dynamism. In his final book, evolutionary biologist Stephen J. Gould stated that the fallacy in these arguments is that natural selection is not an optimizing force. ${ }^{5} \mathrm{~A}$ plant need only reproduce to maintain its place in the community and beyond that threshold, there is no natural force toward optimization. Many plants we consider "native" fare poorly against newer species that never experienced the local habitat or plant community. This has been repeatedly demonstrated by the superior performance of introduced grasses such as smooth bromegrass and crested wheatgrass in comparison to native cool-season species in their home areas. ${ }^{6-10}$ In addition to natural selection, the evolutionary genetic processes of mutation, migration, and drift also determine plant population genetic composition and these processes are random, not optimizing. ${ }^{11}$ Further evidence that local populations are not optimally adapted comes from investigations of Mavraganis and Eckert, who have shown that inbreeding in local types can significantly reduce population fitness. ${ }^{12}$ Optimizing evolution results from intelligent effort: it is not a result of natural randomness. ${ }^{5}$

Natural selection is not an optimizing force.

\section{Intelligent Effort: Developing Plant Materials}

A pragmatic solution to the revegetation problem is the one used to re-seed millions of acres in the Great Plains and the Inter-Mountain West to both native and introduced species during several major revegetation efforts, including the response to the drought of the 1930s and, more recently, the Soil Bank and Conservation Reserve Programs. Native plant cultivar development includes (1) collecting plant materials from broad geographical areas, (2) evaluating them at multiple sites in the intended area of use, and (3) selecting the best accessions. Selections have been increased and released as cultivars, or used in breeding programs for improving specific traits before being "released" as cultivars. ${ }^{13,14}$ New cultivars are released by being officially named and registered with one or more state or national seed certifying organizations 
or agencies. Seed of officially released and registered cultivars can be certified for genetic purity under state and federal seed laws. Examples of native plant cultivars and releases include 'Critana' thickspike wheatgrass, 'Whitmar' bluebunch wheatgrass, 'Nezpar' Indian ricegrass, and 'Trailblazer” switchgrass. The genetic structure of cultivars is known. Their areas of adaptation have been determined by testing and by the known origin of their base germplasm. They are produced under certified conditions to ensure their genetic integrity is maintained..$^{15}$ Because they are produced in commercial seed fields, their seed cost is significantly less than that of seed harvested locally from wild stands.

An alternative procedure advocated by Stutz, particularly for species for which appropriate cultivars are unavailable, is to establish on a revegetated site a mix of seed sources within or among closely related species so genetic mixing and sorting allow those combinations to develop that are adapted and sustainable as the site itself evolves. ${ }^{3,4}$ Stutz's procedure is a plan for preserving local-plant evolution as a key ecological process.

A properly administered seed certification system will prevent seed-increase-related genetic shifts.

\section{Cultivar Genetics and Agronomic Production}

To ensure that native plant cultivars have a significant amount of genetic diversity, cultivars are often produced by intermating or combining numerous plants or accessions from the intended geographical area of use. Two recent studies using molecular genetic markers demonstrated that genetic shifts during seed production are not-detectable for a cross-pollinated species, blue grama, and are small for a self-pollinated species, slender wheatgrass. ${ }^{16,17}$ Larson et al. examined the DNA of bluebunch wheatgrass cultivars, including 'Whitmar', which was released in 1946, and reported high levels of DNA variation were maintained in these cultivars. ${ }^{18}$ The proper use of the seed certification system to produce certified seed prevents significant genetic shifts from occurring during seed increase.

Native-plant cultivars have been used for more than 50 years.

\section{The Question of Genetic Pollution}

Does crossbreeding of local sources with certified sources (particularly cultivars selected for superior characteristics) increase genetic diversity and improve local-stock sustainability, or does it cause a degeneration of local stock (genetic pollution)? More than 50 years of using native-plant cultivars on millions of acres in the Great Plains and Intermountain West has produced no obvious evidence genetic pollution has occurred. But, have we looked? The alternative hypotheses should be tested using molecular genetic markers to measure gene flow among cultivars and native populations, and to assess the effect on progeny populations. It is no more valid to make land management decisions based on fear of genetic pollution (fear of adverse consequences is not evidence of fact), than it is to ignore existing information or the need to properly test the questions.

What is the effect of natural selection on less fit offspring?

\section{Inbreeding and "Outbreeding" Depression}

Inbreeding depression is a valid term describing the well-established loss of vigor that occurs in cross-pollinated species after several generations of self-pollination or sib-mating. "Outbreeding depression" is a relatively new term referring to the loss in vigor, yield, or fitness that may occur when plant materials from different geographical or adaptation regions are intermated. ${ }^{19,20}$ Agronomic plant breeders have long recognized "outbreeding depression" when mating adapted and non-adapted material, but they do not use the term. In breeding programs mal-adapted offspring can be carefully preserved where the material contains desired traits to be transferred to adapted material. In natural systems mal-adapted types do not remain in the plant community-whether or not they have desirable traits. Several studies summarized by Rogers and Montalvo documented the percentage of offspring affected by "outbreeding depression" in native plant populations in the first generation (F1) of wide crosses. ${ }^{19} \mathrm{In}-$ formation is lacking, however, on the effect of subsequent generations of natural selection on the fitness of the derived populations. ${ }^{21,22}$ In crop plants, the equivalent of outbreeding depression results from genetic incompatibility due to cytogenetic differences including inversions, translocations, deletions, and ploidy levels and to linked genes controlling adapted traits that have evolved differently in genetically separated populations of a species. In natural systems natural selection probably makes outbreeding depression a non-relevant question.

\section{Do Cultivars Threaten the Functional Ecology of an Area?}

There is concern that seeded plants or their offspring from crosses with local types may be more vigorous, competitive, or otherwise more fit than the indigenous plants, and may replace local types and negatively affect the species structure within ecosystems. This is another argument from a negative consequence but somewhat the opposite of the genetic-pollution and outbreeding-depression arguments. The evidence against it and the need to directly test the questions are the same. Millions of acres have been seeded to cultivars of native species and during the 50+ years since the first seeding took place there has been no documented negative ecological effects on rangelands. However, the immeasurable ben- 


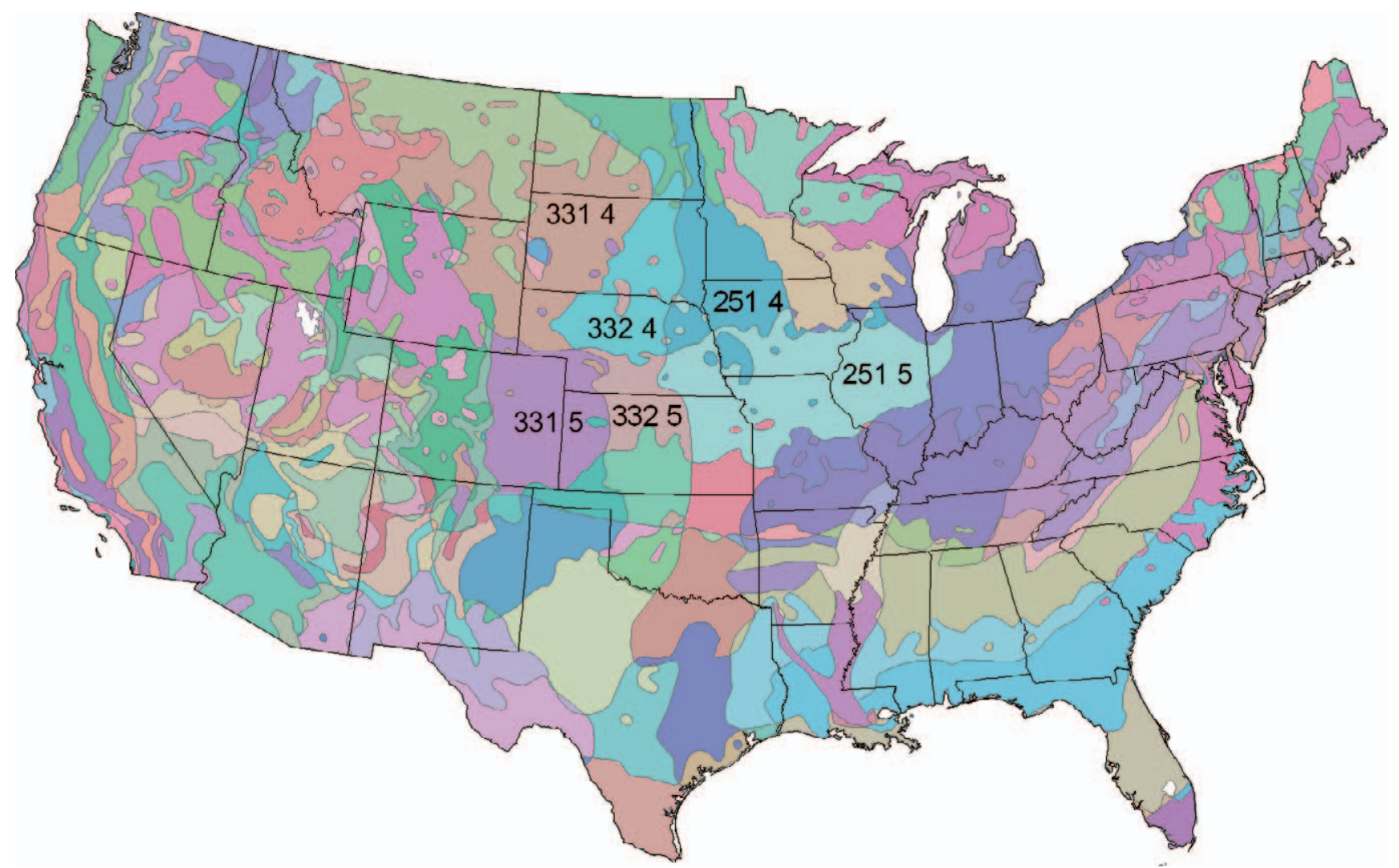

Figure 1. Plant Adaptation Region map for the USA minus Alaska and Hawaii with the following labeled PAR's: PAR $331-4, P A R 331-5=$ Great Plains Palouse Dry Steppe HZ4 and HZ5, respectively; PAR 332-4, PAR 332-5 = Great Plains Steppe HZ 4 and HZ5, respectively; PAR 251-4, PAR 251-5 = Prairie Parkland Temperate HZ 4 and HZ5, respectively. (From Reference 36.)

efit to soil and water conservation, forage production, and wildlife habitat are documented. ${ }^{23}$ It has been difficult to determine which plants in an area are descendents of indigenous or seeded populations, but the use of molecular markers will now make this research feasible if funding is available. As argued earlier, the alternative hypotheses should be tested. The results should also be compared with Rogers and Montalvo's reported adverse effect of species hybridization within wetland systems, including hybridizations involving Spartina sp. ${ }^{19}$

Is the postulated problem even remotely as serious as the ecological problems solved by using the released materials?

\section{Revegetation Experience}

The revegetation industry's conventional practice is to use certified seed of cultivars, seed with source-identified certification, or seed from other proven sources. The reasons are availability, economics, and results. Seed of local types-if available-is usually expensive ${ }^{24-26}$ (M. Majerus, personal communication, 2003) and the quantity and quality varies widely with the weather. ${ }^{27}$ Businesses stay in business by being successful and the result is local seed is rarely used by private enterprise. Mined-land revegetation projects are continually monitored by state environmental regulatory agencies. Monitored projects, seeded with cultivars and other certified seed sources, have been generally successful and approved because they have restored fundamental ecosystem processes and because no calamitous consequences of using non-local seed have been observed in or around the projects. The preponderance of over 50 years of revegetation experience and evidence supports the use of certified seed from proven sources.

\section{Adaptation Regions}

Species within an ecoregion are not genetically uniform in regards to adaptation to the entire ecoregion, but are stratified into a north to south latitudinal gradient or high to low elevation gradient of ecotypes that are best adapted to their own specific area of the ecoregion. ${ }^{28-34}$ Substantial research resources are often available for agronomic and horticultural crops and specific adaptation information is developed by extensive testing. Similar information is needed for native plants. Geographical adaptation areas have been defined us- 
ing trial plantings, for cultivars of native grasses grown in the Great Plains. The areas are based on Plant Hardiness Zones that are about 250 miles wide. ${ }^{35}$ The studies listed previously indicate that most native grass cultivars can be grown in their origin Hardiness Zone and about half of the adjacent north or south zones in The Great Plains and Midwest. These studies and other available trial information and field experience demonstrate that the adaptation areas of many native plant cultivars are very extensive rather than intensive-again, a fact to be expected given the change scenarios of paleohistory as described by Delcourt and Delcourt. ${ }^{2}$ As long as plant-materials seed stocks are grown in areas with similar photo-periods and a minimal-length growing season, there should not be genetic shifts in the populations during seed production. If the photo-period criterion is met and if the growing season allows for seed production prior to a killing frost, then it is not necessary to grow seed in the same location in which it will be utilized. ${ }^{16}$

Many native plant cultivars have extensive areas of adaptation.

PARs establish a model for testing plant adaptation.

Ecoregions and plant hardiness zone classification systems integrate climatic and geographic variables that determine plant adaptation. Vogel (co-author) and others have developed Plant Adaptation Regions (PARs) ${ }^{36}$ for the USA by merging Bailey's widely used ecoregion map ${ }^{37,38}$ and the USDA Plant Hardiness Zone Map (Figure1). ${ }^{39}$ Based on their geographic origin, plant materials can be classified for their general adaptation areas using PARs. Great Plains research on plant adaptation supports the use of PARs and indicates that cultivars can be adapted to several PARs - thus PARs establish a structure or model for adaptation trials. However, there is limited information available on many species, and resources for testing adaptation of ecotypes, seed sources, and strains of native species are sparse.

The lack of precise boundaries in natural environments should be recognized. Both Bailey's ecoregion concept and plant hardiness zones attempt to define areas of plant adaptation based on environmental factors that gradually change across the landscape. Because of the gradual change in environmental factors that control plant growth, any system that defines boundaries based on these factors is not absolute but requires judgment on the part of the users. It should be noted that the PARs cover large geographical areas and that they do not coincide with political boundaries. There is no scientific database to support mandating the use of local ecotype plant materials on a mileage or political-boundary basis.

\section{Summary and Conclusions}

Native-plant species and their ecotypes and populations have values that make plant-type preservation a valid and important consideration. But, disturbed lands are not preserves. Revegetation is about performance in the face of challenging environmental conditions and highly competitive invasive weeds. Common-sense budgetary constraints and concern for fundamental ecological processes-including genetic mixing and sorting - and invasive-weed exclusion should be the priority revegetation considerations. An undue revegetaton emphasis on using local types is a concern because of the lower quantity and quality, and higher costs associated with using local seed and because of gene-pool isolation and limitation on disturbed sites. Native-plant husbandry is an exercise of science and intellect over natural randomness and has resulted in cultivars bred and selected for desirable characteristics, including superior performance in germination, seedling vigor, early growth, and tolerance to stress. Cultivars often have a broad genetic base and are likely to possess more genetic diversity than that of native local populations. Federal and State programs have contributed the bulk of the material and technology now used in ecosystem restoration and those programs are a foundation upon which future work should be based. That work should continue and should include an enlarging of our knowledge of genetic processes and consequences, adaptation, and sustainability. The development of molecular markers to monitor genetic changes in plant populations enables debated questions to be addressed, but funding is needed for this research.

The complexities of today's natural-resource challenges emphasize a need for effective plant-materials choices to sustain basic, ecosystem functions and processes including the processes involved in plant adaptation to an ever-changing world. Revegetation is a needed means of mitigating ecological insults. Neil West captured in 10 words the essence of revegetaion priorities when he wrote, "it is more important to preserve processes than all organisms ..." 40 This requires the full use of science, intellect, and decades-acquired revegetation experience and knowledge.

Authors are with USDA-ARS, High Plains Grasslands Research Station, Cheyenne, WY (Booth); and Grain, Forage, and Bioenergy Research Unit, Lincoln, NE (Vogel).

\section{Literature Cited}

1. Leopold, A. 1980. A Sand County almanac with essays from Round River. New York, NY: Ballantine Books. p168.

2. Delcourt, P. A., And H. R. Delcourt. 2003. Paleoclimates, paleovegetation, and paleofloras of North America north of Mexico during the late Quaternary, Ch. 4. In: Flora of North America. http://hua.huh.harvard.edu/FNA/Volume/V01/ Chapter04. shtml. Accessed November 2003.

3. Stutz, H. C. 1982. Broad gene pools required for disturbed lands. In: E. F. Aldon, W. R. Oaks [eds.], Symposium: 
Reclamation of mined lands in the Southwest. Albuquerque, NM: Soil Conservation Society of America, New Mexico Chapter. p 113-118.

4. Stutz, H. C. 1989. Evolution of shrubs. In: C. M. McKell [ed.]. The biology and utilization of shrubs. San Diego, CA: Academic Press Inc. p 323-340.

5. Gould, S. J. 2002. An evolutionary perspective on native plants. In: I have landed. New York, NY: Harmony Books. p 335-346.

6. Robertson, J. H., and C. K. Pierce. 1945. Artificial seeding in closed communities. Northwest Science 19:58-66.

7. Harris, G. A. 1977. Root phenology as a factor of competition among grass seedlings. Journal of Range Management 30:172-177.

8. Schuman, G. E., F. Rauzi, and D. T. Воотн. 1982. Production and competition of crested wheatgrass-native grass mixtures. Agronomy Journal 74:23-26.

9. Brown, C. S., And K. J. Rice. 2000. The mark of Zorro: effects of the exotic annual grass Vulpia myuros on California native perennial grasses. Restoration Ecology 8:10-17.

10. Asay, K. H., W. H. Horton, K. B. Jensen, and A. J. Palazzo. 2001. Merits of native and introduced Triticeae grasses on semiarid rangelands. Canadian Journal of Plant Science 81:45-52.

11. Falconer, D. S. 1981. Introduction to quantitative genetics. 2nd ed. New York, NY: Longman. 340 p.

12. Mavraganis, K., and G. Eckert. 2001. Effects of population size on reproductive output in Aquilegia canadensis (Ranunculaceae). Oikos 95:300-310.

13. Vogel, K. P., and J. F. Pedersen. 1993. Breeding systems for cross-pollinated perennial grasses. Plant Breeding Reviews 11:251-274.

14. Vogel, K. P., And B. Burson. 2004. Breeding and Genetics. In: L. E. Moser, B. Burson and L. Sollenberger [eds.]. Warm-season $\left(\mathrm{C}_{4}\right)$ grasses. Madison,WI: ASA-CSSA-SSSA. Agronomy Monograph 45. p 51-96.

15. Fenr, W. R. 1987. Principles of cultivar development. Vols.1 \& 2. New York, NY: Macmillan. 725 p.

16. Fu, Y. B., Y. S. N. Ferdinandez, A. T. Phan, B. Coulman, and K.W. Richards. 2004. AFLP variation in four blue grama seed sources. Crop Science 44:383-288.

17. Ferdinandez, Y. S. N., B. E. Coulman, and Y-B. Fu. 2005. Detecting genetic changes over two generations of seed increase in an awned slender wheatgrass population using AFLP markers. Crop Science 45:1064-1068.

18. Larson, S. R., T. A. Jones, Z. M. Hu, C. L. McCracken, and A. Palazzo. 2000. Genetic diversity of bluebunch wheatgrass cultivars and a multiple-origin polycross. Crop Science 40:1142-1147.

19. Rogers, D. L., And A. M. Montalvo. 2004. Genetically appropriate choices for plant materials to maintain biological diversity. University of California. Report to the USDA Forest Service, Rocky Mountain Region, Lakewood, CO. Available at: http://www.fs.fed.us/r2/publications/botany/plantgenetics.pdf.:343.

20. Jones, T. A. 2005. Just the FAQs, please just the FAQs. Native Plants Journal 6:14-24.
21. Hufford, K. M., and S. J. Mazer. 2003. Plant ecotypes: genetic differentiation in the age of ecological restoration. TRENDS in Ecology and Evolution 18(3):147-155.

22. Lynch, M., And B. Walsh. 1998. Genetics and analyses of quantitative traits. Sunderland, MA: Sinauer Associates, Inc. $980 \mathrm{p}$.

23. Booth, D. T., And J. T. Jones. 2000. Plants for ecological restoration: a foundation and a philosophy for the future. Native Plant Journal 2:12-20.

24. Scianna, J. D., G. M. Schaefer, and M. E. Majerus. 2001. Development and use of cost estimate matrices for project planning and evaluation. USDA-NRCS Plant Materials Technical Note No. MT-39. Available at: http://Plant-Materials.nrcs. usda.gov. Accessed November 2003.

25. Hijar, D. 2003. Revegetating the west: where is it going. Rangelands 25:50-51.

26. Winslow, S., And M. Majerus. 2002. Wildland collection of native seed for agronomic production. Kansas City, MO: Abstracts, Annual Meeting of the Society for Range Management, \# 77.

27. Boоth, D. T., Y. BAI, And E. E. Roos. 2003. Wyoming Big sagebrush seed production from mined and un-mined rangelands. Journal of Range Management 58:188-193.

28. Cornelius, D. R., And C. O. Johnston. 1941. Differences in plant type and reaction to rust among several collections of Panicum virgatum L. Journal of American Society of Agronomy 33:115-124.

29. McMillian, C. 1959. The role of ecotypic variation in the distribution of the central grassland of North America. Ecological Monographs 29:285-308.

30. McMillian, C. 1965. Ecotypic differences with four North American prairie grasses: II. Behavioral variation with transplanted community fractions. American Journal of Botany 52:55-65.

31. McMillian, C., And J. Weiler. 1959. Cytogeography of Panicum virgatum in central North America. American Journal of Botany 46:590-593.

32. Newell, L. C. 1968. Effects of strain source and management practice on forage yields of two warm-season prairie grasses. Crop Science 8:205-210.

33. Phan, A. T., and S. R. Smith Jr. 2000. Seed yield variation in blue grama and little bluestem plant collections in southern Manitoba, Canada. Crop Science 40:555-561.

34. Casler, M. D., K. P. Vogel, C. M. Taliaferro, and R. E. Wynia. 2004. Latitudinal adaptation of switchgrass populations. Crop Science 44:293-403.

35. Moser, L. E., And K. P. Vogel. 1995. Switchgrass, big bluestem, and indiangrass. In: R. F. Barnes et al. [eds.]. Forages (5th ed.) Vol. I. An introduction to grassland agriculture. Ames, IA: Iowa State University Press. p 409-420.

36. Vogel, K. P., M. R. Schmer, and R. B. Mitchell. 2005. Plant adaptation regions: ecological and climatic classification of plant materials. Rangeland Ecology and Management 58:315-319.

37. Bailey, R. G. 1995. Description of the ecoregions of the United States. 2nd ed. Miscellaneous Publication 1391. Washing- 
ton, DC: USDA, Forest Service. 108 p. with separate map at $1: 7,500,000$.

38. Bailey, R. G. 1997. Map: Ecoregions of North America (rev). USDA Forest Service in cooperation with The Nature Conservancy and the US Geological Survey. Washington, DC: USDA, Forest Service. Available at: www.fs.fed.us/colorimagemap/ ecoreg1_provinces. Accessed 1 September 2004.
39. Cathey, H. M. 1990. USDA Plant Hardiness Zone Map. USDA Miscellaneous Publication 1475. Washington, DC: US National Arboretum, Agricultural Research Service, USDA. Available at: www.usna.usda.gov/Hardzone/ushzmap.html. Accessed 1 September 2004.

40. West, N. E. 1993. Biodiversity of rangelands. Journal of Range Management 46:2-13.

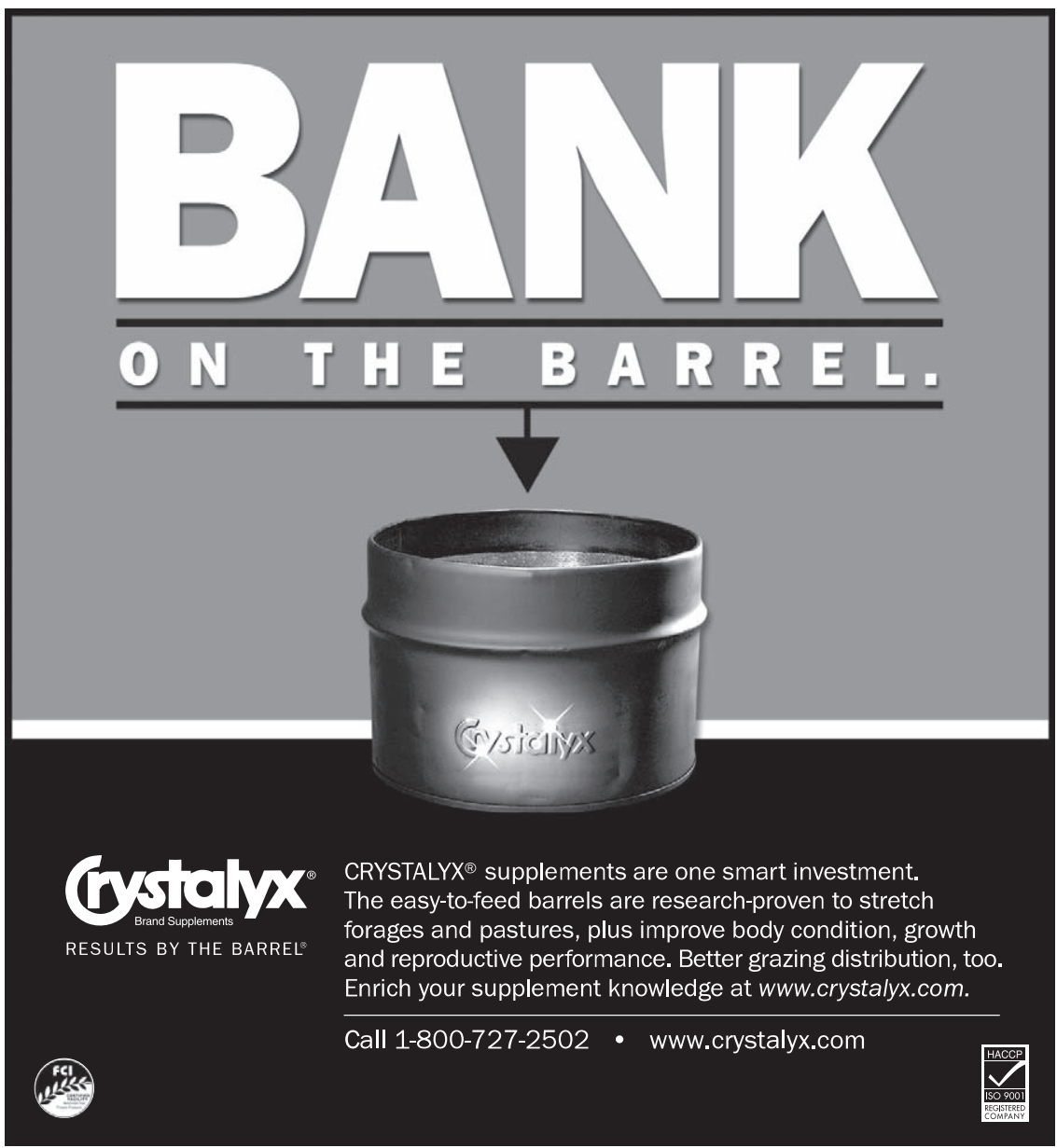

